\title{
Clinical and pathologic perspectives on aspirin sensitivity and asthma
}

Donald D. Stevenson, MD, ${ }^{\mathbf{a}}$ and Andrew Szczeklik, MD ${ }^{\mathbf{b}}$ La Jolla, Calif, and Krakow, Poland

This activity is available for CME credit. See page 38A for important information.

\begin{abstract}
Aspirin and other nonsteroidal anti-inflammatory drugs that inhibit COX-1 induce unique nonallergic reactions, consisting of attacks of rhinitis and asthma. These hypersensitivity reactions occur in a subset of asthmatic subjects, thus identifying them as having this exclusive clinical presentation. We refer to these patients as having aspirin-exacerbated respiratory disease, a disease process that produces devastating eosinophilic inflammation of both the upper and lower respiratory tracts. This review focuses on a description of patients with aspirin-exacerbated respiratory disease, methods available to diagnose their condition, the unique ability of all nonsteroidal anti-inflammatory drugs that inhibit COX-1 to cross-react with aspirin, an update on pathogenesis, and current thoughts about treatment. (J Allergy Clin Immunol 2006;118:773-86.)
\end{abstract}

Key words: Aspirin, nonsteroidal anti-inflammatory drugs, asthma, nasal polyps, chronic hyperplastic eosinophilic sinusitis, aspirinexacerbated respiratory disease, aspirin desensitization

In 1922, Widal et al $^{1}$ published the first article describing the association of aspirin sensitivity, asthma, and nasal polyposis. They also conducted the first aspirin challenges and desensitization. This syndrome was not widely recognized, however, until Samter published 2 articles in the late 1960s and called the condition Samter's

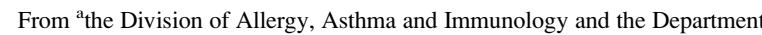
of Medicine, Scripps Clinic and the Scripps Research Institute, La Jolla, and ${ }^{b}$ the Department of Medicine, Jagellonian University School of Medicine, Krakow.

Disclosure of potential conflict of interest: D. D. Stevenson has received the Skaggs Scholarship Institutional Grant and study grants from Merck and Novartis, is employed by the Scripps Clinic and The Scripps Research Institute, and is on the speakers' bureau for Merck and Critical Therapeutics. A. Szczeklik declares that he has no conflict of interest.

Received for publication June 16, 2006; revised July 6, 2006; accepted for publication July 7, 2006.

Available online September 4, 2006.

Reprint requests: Donald D. Stevenson, MD, Scripps Clinic, 10666 N Torrey Pines Rd, La Jolla, CA 92037. E-mail: dstevemd@AOL.com or Stevenson. donald@scrippshealth.org. 0091-6749/\$32.00

(C) 2006 American Academy of Allergy, Asthma and Immunology doi:10.1016/j.jaci.2006.07.024
Abbreviations used

AERD: Aspirin-exacerbated respiratory disease

CHES: Chronic hyperplastic eosinophilic sinusitis

cysLT ${ }_{1}$ RA: Cysteinyl leukotriene receptor antagonist 1 EP: E-prostanoid

FLAP: 5-Lipoxygenase-activating protein

HETE: Hydroxy-eicosatetraenoic acid

5-LO: 5-Lipoxygenase

5-LOINH: 5-Lipoxygenase inhibitor

LT: Leukotriene

$\mathrm{LTC}_{4} \mathrm{~S}$ : Leukotriene $\mathrm{C}_{4}$ synthase

NSAID: Nonsteroidal anti-inflammatory drug

PG: Prostaglandin

SNP: Single nucleotide polymorphism

$\mathrm{uLTE}_{4}$ : Urinary leukotriene $\mathrm{E}_{4}$

triad (asthma, nasal polyps, and aspirin reactions). ${ }^{2,3}$ Most clinical investigators now include chronic hyperplastic eosinophilic sinusitis (CHES) ${ }^{4}$ as a fourth hallmark of aspirin-exacerbated respiratory disease (AERD). ${ }^{5}$

Many other terms have been used to describe this respiratory disease: aspirin-induced asthma, aspirinsensitive asthma, aspirin hypersensitivity, aspirin idiosyncrasy, and aspirin intolerance. All terms refer to the same patients who are afflicted with intractable inflammation in both the upper and lower respiratory tracts (nasal polyps, CHES, and asthma). Exposure to aspirin does not initiate or even perpetuate the underlying respiratory inflammatory disease. However, once the disease is ongoing, aspirin and nonsteroidal anti-inflammatory drugs (NSAIDs) induce release or synthesis of critical mediators, which then cause all of the clinical manifestations of the characteristic respiratory reactions. The recent consensus nomenclature to describe aspirin-induced respiratory reactions is nonallergic hypersensitivity reactions. ${ }^{6}$

\section{PREVALENCE}

Identifying the exact prevalence of AERD is difficult. Many patients have the disease but do not know it because 
they have not ingested aspirin and other NSAIDs (usually acetaminophen users). Alternatively, they experienced mild asthma attacks after ingesting NSAIDs but did not correlate these events. In a large survey of pharmacyreported reactions to analgesics in asthmatic subjects, the prevalence of AERD was listed as 3\% in adults and 2\% in children. ${ }^{7}$ In large population surveys, using questionnaires to ask about asthma and aspirin inducing shortness of breath or asthma attacks, the prevalence was $1.2 \%$ (sample size, 4300), ${ }^{8}$ but the incidence of aspirin sensitivity was much higher in patients whose physician made a diagnosis of asthma (8.8\%). In a large population survey in Poland (12,971 adults), $4.3 \%$ of asthmatic subjects identified themselves as reacting to aspirin with asthmatic attacks. ${ }^{9}$ In Perth, Australia, in a survey of 516 asthmatic patients and 1298 randomly selected individuals, the prevalence was reported to be $11 \%$ among asthmatic subjects and $2.5 \%$ among the general population. ${ }^{10}$

Investigators have performed prospective oral aspirin challenges on various populations of asthmatic patients to circumvent the problem of prior nonexposure to aspirin/ NSAIDs in asthmatic patients. During such aspirin challenge studies in adult asthmatic subjects, the incidence of AERD has ranged from $10 \%$ to $20 \%$ in the pre- 1990 literature. ${ }^{11-14}$ In a meta-analysis of 15 studies performed after 1990 using oral aspirin challenges to detect aspirin hypersensitivity in asthmatic populations, the combined prevalence was $21 \%$ (CI, 14\% to $29 \%$ ), whereas in 5 studies in children (0-18 years) the combined prevalence was only $5 \%$ (CI, $0 \%$ to $14 \%)^{7}$

When target populations of asthmatic subjects are further stratified and include only those who also had nasal polyps and chronic sinusitis, the prevalence of aspirin hypersensitivity, discovered by means of prospective oral aspirin challenges, was found to be even higher, in the range of $30 \%$ to $40 \%{ }^{11,15}$ In fact, the one study in children that stands out as having a high incidence of positive oral aspirin challenge results (28\%) was actually in a population of teenagers who had nasal polyps, chronic sinusitis, severe asthma, and a high prevalence of steroid dependency. ${ }^{16}$ Teenagers are probably more like adults than prepubertal children with respect to being vulnerable to acquiring AERD. The general experience is that aspirin/ NSAID hypersensitivity in preschool asthmatic subjects is incredibly rare.

Asthmatic patients who reported a history of aspirin- or NSAID-induced asthma attacks (ie, believed they were "aspirin sensitive") experienced positive oral aspirin challenges of $66 \%,{ }^{13} 84 \%,{ }^{17}$ and $97 \%{ }^{11}$ of the time in these 3 studies. These observations point out the problem of overdiagnosing AERD when relying on a history of asthma after ingestion of aspirin or NSAIDs. In some patients a coincidence occurred in that aspirin or an NSAID was ingested within 3 hours of the asthma attack, but the 2 events were unrelated to each other. The best histories include ingestion of a therapeutic dose of any NSAID that preferentially inhibits COX-1, followed by a severe asthma attack requiring emergency intervention, an NSAID-associated asthma attack at another time, or both.

\section{NATURAL HISTORY AND CLINICAL PRESENTATION OF AERD}

Consistent with a low prevalence of AERD in preteenagers, AERD is an acquired disorder with an onset of symptoms beginning somewhere between the teenage years and age 40 years. The average ages of onset were 34 and 29 years in 2 large studies involving 300 and 500 patients with AERD, respectively. ${ }^{18,19}$ There are more female than male subjects who acquire this disease: in a study of 300 patients from the United states, ${ }^{18}$ a $3: 2$ ratio of female/male sex was found, whereas in Europe ${ }^{19}$ a 2.3:1 ratio was found. There is no racial or ethnic predilection for acquiring AERD. Family histories of AERD are rare and reported in $6 \%$ of patients in the European survey ${ }^{19}$ but in only $1 \%$ of patients in the US series. ${ }^{18}$

Aspirin hypersensitivity can appear in patients who already have allergic rhinitis and allergic asthma or any other provoking factor for their asthma (eg, gastroesophageal reflux disease, viral respiratory tract infections, irritant inhalation, or exercise) or it can appear in patients de novo who have never had any prior respiratory disease. In a review of 103 German and Polish patients with AERD, 34\% had positive skin prick test responses to at least one aeroallergen. ${ }^{19}$ In the United States series of 300 patients with AERD, the prevalence of positive wheal-and-flare skin test responses was $64 \%$ but included both prick and intradermal testing. ${ }^{18}$

The first clinical manifestation of AERD is usually nasal congestion, but it might be superimposed on patients who already have allergic rhinitis. Many patients remember an upper respiratory tract viral infection as the inciting event ("My cold never went away"). In 1988, Szczeklik ${ }^{20}$ presented a theory that a viral respiratory tract infection might be an inciting event that starts the inflammatory cascade, leading to AERD in genetically susceptible individuals. Another idea is that diesel exhaust and cigarette smoke exposure, both of which contain polyaromatic hydrocarbons, such as benzopyrene and phenanthrene, stimulate respiratory epithelial cells to synthesize cytokines (IL-1, IL-6, IL-16, and GM-CSF), which drives a $\mathrm{T}_{\mathrm{H}} 2$ response. ${ }^{21-25}$ In an epidemiologic study a significantly higher prevalence of exposure to passive cigarette smoke during childhood and young adult life was found in patients with AERD when compared with their asymptomatic spouses, acting as control subjects (unpublished data, J. Martin and D. D. Stevenson). Hyposmia or anosmia occurs in most patients with AERD. In fact, normal olfaction correlates with not having AERD. ${ }^{26}$

In AERD the original chronic rhinitis progresses to CHES with nasal polyposis. Computed tomography or plain radiography of the sinuses revealed opacifications in 99\% of patients in one study. ${ }^{18}$ In this same study $94 \%$ of patients with AERD had undergone at least 1 and averaged 3 prior sinus and polyp operations. ${ }^{18}$

Asthma was either previously present in childhood and young adult life (usually IgE mediated) or begins de novo between 3 months and up to 5 years (average, 2 years) after onset of nasal congestion and polyposis. ${ }^{19}$ Aspirin/ 
NSAID-induced hypersensitivity respiratory reactions can appear at any time in the course of the disease, but until such an event occurs, the diagnosis of AERD cannot be considered. Despite avoidance of aspirin and NSAIDs, mucosal inflammation of the upper and lower respiratory tracts persists and progresses. This strongly supports the fact that ingestion of aspirin and the older NSAIDs exacerbate an inflammatory condition that is already active, rather than being responsible for inducing the disease in the first place.

\section{RESPIRATORY REACTIONS TO ASPIRIN AND NSAIDs}

\section{Cross-reactions among the NSAIDs that inhibit COX-1}

Patients with AERD react to aspirin, as well as all older NSAIDS that preferentially inhibit COX-1 (Table I), inducing a spectrum of respiratory reactions, including rhinitis and conjunctivitis, laryngeal spasm, and asthma attacks. $^{27-31}$ The reactions usually occur within 30 to 60 minutes after ingesting full therapeutic doses of aspirin or NSAIDs but can occur up to 3 hours later, particularly when patients are challenged with smaller aspirin doses in the range of 30 to $100 \mathrm{mg}$. Assuming that the doses of NSAIDs are in the therapeutic range, cross-reactivity among NSAIDs that inhibit COX-1 is $100 \%$ (Table I).

In a study of 300 patients in the United States with documented AERD, aspirin was the most commonly reported NSAID $(80 \%)$ to elicit prior respiratory reactions, followed by ibuprofen $(41 \%) .{ }^{18}$ Of the 300 patients, $36 \%$ experienced 3 or more previous respiratory reactions to aspirin and NSAIDS, indicating that a third of patients had a significant delay in diagnosis. This suggested either observational confusion on the part of the patients and their physicians or insufficient education by health care providers regarding avoidance strategies. ${ }^{18}$

\section{Partial cross-reactivity with poor inhibitors of COX-1}

Salsalate and acetaminophen are poor inhibitors of COX-1 (Table II). However, at high doses, both can induce mild respiratory reactions in patients with AERD. Most patients with AERD can safely tolerate up to 500 mg of acetaminophen, but $28 \%$ experienced mild respiratory reactions to $1000 \mathrm{mg}$ of acetaminophen, and another $6 \%$ reacted when doses were increased to $1500 \mathrm{mg}^{32} \mathrm{~Pa}$ tients with AERD can take salsalate in doses of less than $2000 \mathrm{mg} .{ }^{33}$ However, when $2000 \mathrm{mg}$ was given to patients with AERD, mild respiratory reactions occurred in $10 \%$ of patients undergoing oral challenges with salsalate. When reactions are elicited at higher doses of acetaminophen and salsalate, they tend to be milder than those observed with the older NSAIDs.

\section{Partial cross-reactivity with partially selective COX-2 inhibitors}

Meloxicam and nimesulide (Table II) are 2 anti-inflammatory drugs that preferentially inhibit $\mathrm{COX}-2$ at lower
TABLE I. Universal cross-reactions between aspirin and non-NSAIDs occur

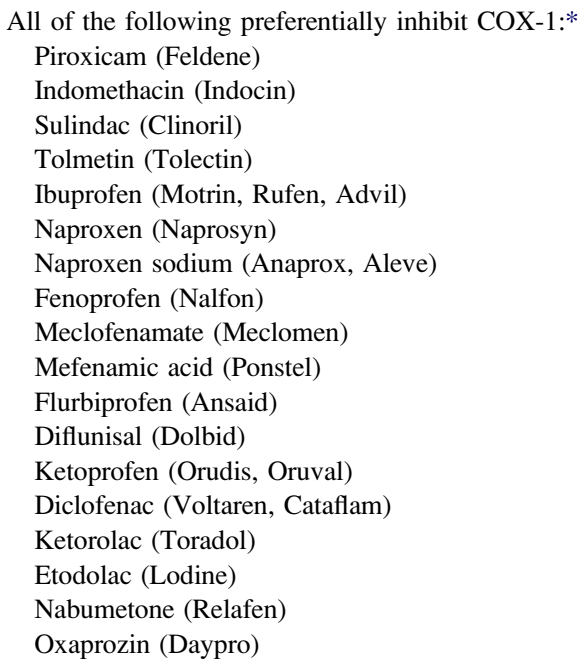

*Generic name (brand names).

concentrations but inhibit $\mathrm{COX}-1$ at higher therapeutic concentrations (ie, $15 \mathrm{mg}$ of meloxicam). ${ }^{34-36}$ Similar to salsalate and acetaminophen, respiratory reactions can occur with higher doses of these 2 drugs and tend to be relatively mild. ${ }^{37,38}$ Only meloxicam is available in the United States, but both are available worldwide.

\section{Unusual cross-reactivity with selective cOX-2 inhibitors}

Selective COX-2 inhibitors, such as rofecoxib, celecoxib, valdecoxib, etoricoxib, parecoxib, and lumiracoxib, are the most recent category of NSAIDs to enter and, for some, to then exit the market (Table III). Many clinicians are apprehensive about prescribing selective COX-2 inhibitors to patients with AERD because warning labels on all coxibs list "aspirin triad" as a contraindication for prescribing these drugs. Since 2001, well-designed studies, however, demonstrated that selective COX-2 inhibitors, given in therapeutic dosages, have not crossreacted with aspirin or NSAIDs in any patients with AERD participating in these studies.

In a double-blind placebo-controlled trial, Stevenson and Simon $^{39}$ challenged 60 patients with AERD with rofecoxib. None of the patients reacted after ingesting 12.5 $\mathrm{mg}$ and $25 \mathrm{mg}$ of rofecoxib. Martin-Garcia et $\mathrm{al}^{40}$ and Szczeklik et $\mathrm{al}^{41}$ conducted single-blind challenges in a total of 52 more patients with AERD with up to $25 \mathrm{mg}$ of rofecoxib, and none reacted. Woessner ${ }^{31}$ challenged 60 patients with AERD with even higher doses of rofecoxib (50 mg or 2 times the therapeutic dose), and again, none of the patients had any adverse reactions. Rofecoxib has been withdrawn from the market.

Celecoxib has also been studied in patients with AERD. Yoshida et $\mathrm{al}^{42}$ challenged 17 patients with AERD with $200 \mathrm{mg}$ of celecoxib, and none reacted. Woessner et $\mathrm{al}^{43}$ 
TABLE II. Cross-reactions with aspirin occur with higher doses of these drugs

A. NSAIDs that are poor inhibitors of COX-1

Acetaminophen (paracetamol) (Tylenol)

Salsalate (Disalcid)

B. NSAIDs that preferentially inhibit COX-2 at lower doses but also inhibit COX-1 when higher doses are given

Nimesulide (Aulin, Nimesil)

Meloxicam (Mobic)

conducted double-blind placebo-controlled challenges in which 60 patients with AERD were given $200 \mathrm{mg}$ of celecoxib, and none of the patients reacted. Gyllfors et $\mathrm{al}^{44}$ challenged 32 patients with AERD with $400 \mathrm{mg}$ of celecoxib, and again, none of the patients reacted. Furthermore, there was no increase in urinary leukotriene $\mathrm{E}_{4}\left(\mathrm{uLTE}_{4}\right)$ levels during celecoxib challenges, but the usual increase in $\mathrm{uLTE}_{4}$ levels occurred when the same patients were challenged with aspirin.

Valdecoxib is also a COX-2 inhibitor that entered and then exited the US market. Woessner ${ }^{31}$ completed a double-blind placebo-controlled study of 70 patients with proved AERD. None of the patients had adverse reactions to $20 \mathrm{mg}$ of valdecoxib. Etoricoxib is another highly selective COX-2 inhibitor and is available by prescription outside the United States. By experience, it has been well tolerated by patients with AERD. In a recent report from Italy, 27 subjects with mostly urticarial and angioedema reactions to NSAIDs, only 3 of whom had AERD, underwent challenges with a new selective COX-2 inhibitor, parecoxib. ${ }^{45}$ None reacted to parecoxib, which is the first injectable coxib. Lumiracoxib is another coxib available outside the United States. ${ }^{46}$ We did not find case reports of respiratory reactions to lumiracoxib.

However, a word of caution; despite all of the safety data and lack of cross-reactivity for use of selective COX-2 inhibitors in large numbers of patients with AERD, rare case reports of respiratory reactions to selective COX-2 inhibitors have appeared in the literature. A most instructive case was reported by Baldassarre et al. ${ }^{47}$ They described a 45-year-old woman with AERD who experienced asthma attacks by history after paracetamol $(500 \mathrm{mg})$ and by oral challenge after aspirin (10 mg) and celecoxib (15 mg). In addition, during her respiratory reaction to celecoxib, her $\mathrm{uLTE}_{4}$ level increased from a baseline value of 368 to $1318 \mathrm{pg} / \mathrm{mg}$ creatinine. Her unusual sensitivity to aspirin $(10 \mathrm{mg})$ is in contrast to the average aspirin provoking dose of $60 \mathrm{mg}$ (range, $30-100 \mathrm{mg}$ ), which is characteristic of large numbers of patients with AERD undergoing oral aspirin challenges. ${ }^{48}$ One of the authors of this review (AS) has recently worked with a 30-year-old woman with AERD who had very high baseline uLTE 4 levels (40 times the upper limit of normal). During oral challenges, she reacted with bronchospasm after celecoxib and went into anaphylactoid shock after aspirin. Similar case reports for celecoxib, ${ }^{49}$ rofecoxib, ${ }^{38,50}$ and etoricoxib ${ }^{51}$ make it impossible to take the position that coxibs never induce respiratory reactions in patients with AERD.
TABLE III. Selective COX-2 inhibitors preferentially inhibit COX-2

\section{Celecoxib (Celebrex)* \\ Rofecoxib (Vioxx) $\dagger$ \\ Valdecoxib (Bextra) $\dagger$ \\ Etoricoxib (Arcoxia) \\ Parecoxib (Dynastat) $\ddagger$ \\ Lumiracoxib (Prexige) $\$$}

In vitro studies show that in supertherapeutic concentrations of these drugs, weak inhibition of COX-1 occurs.

*Available worldwide.

$†$ Removed from the world market in 2004 and 2005

$\$$ Available outside the United States.

It is difficult to understand the mechanisms that might account for the case reports described above. COX-2 inhibitors are designed with a side arm so that their entrance into the smaller COX-1 channel is prevented by the reduced size of the entrance and lack of a side pocket within the enzyme. ${ }^{52}$ Because of this feature, COX-2 inhibitors are between 5- and 50-fold more selective for COX-2 over COX-1. ${ }^{53}$ Therefore with very high doses of selective COX-2 inhibitors, one could envision such a high drug concentration around the mouth of the COX1 enzymes that arachidonic acid could not enter the channel. However, low to usual therapeutic doses of COX-2 inhibitors have participated in what on the surface appear to be cross-reactions. ${ }^{47}$ We are not able to explain why these rare reactions occur, but genetic differences in the structure of the COX-1 channel would be interesting to investigate.

Some patients with AERD rarely experience respiratory, urticarial, and anaphylactic reactions through immune recognition of a specific COX-2 inhibitor. ${ }^{54}$ It is well known that COX-2 inhibitors, like any of the NSAIDs, can induce IgE-mediated reactions. ${ }^{54-56}$ In other words, patients with AERD are not protected from experiencing other types of specific immune reactions that have nothing to do with inhibition of COX-1. Whatever the mechanisms, as prescribing physicians, we can never guarantee that patients will not react to a selective COX-2 inhibitor. It seems logical to us to give the first full dose of a COX-2 inhibitor in the physician's office to patients with AERD or asthmatic subjects with unknown sensitivities. Unfortunately, because of an increase in cardiovascular adverse events, rofecoxib and valdecoxib were withdrawn from the world market. Currently, the only remaining selective COX-2 inhibitor in the United States is celecoxib. Outside the United States, etoricoxib, parecoxib, and lumiracoxib are available (Table III).

\section{DIAGNOSIS OF AERD}

The diagnosis of AERD can be definitively established only through provocative aspirin challenges. ${ }^{26}$ There is no reliable in vitro test, but the search for one continues. ${ }^{57,58}$ There are 4 types of provocation challenges, depending on 
the route of administration and challenge drug: oral, ${ }^{26,59}$ inhalational, ${ }^{60-62}$ nasal, ${ }^{63-65}$ and intravenous. ${ }^{66}$

In the United States oral aspirin challenges are available. ${ }^{26}$ Details for conducting these challenges can be found in a prior reference. ${ }^{26}$ Instead of starting with $30 \mathrm{mg}$ of ASA during oral challenges, one can cut ASA $81 \mathrm{mg}$ in half and then a quarter and start with $20.25 \mathrm{mg}$ of ASA.

Patients are instructed to continue oral and topical corticosteroids, long-acting bronchodilators, cysteinyl leukotriene receptor antagonist 1 (cysLT $\left.\mathrm{T}_{1} \mathrm{RA}\right)$, 5-lipoxygenase inhibitor (5-LOINH), and systemic corticosteroids because discontinuing these medications can lead to an increase of hyperirritable airways. Some medications should be discontinued 24 hours before challenge, including antihistamines and short-acting inhaled $\beta$-agonists or anticholinergics. Antihistamines can block upper respiratory tract reactions to aspirin, which can interfere with accurate identification of patients with AERD. ${ }^{67}$ Use of short-acting $\beta$-agonists or anticholinergics can lead to false-positive reactions because once the shortacting bronchodilator effect has disappeared, a rapid decrease in lung function can occur. If a decrease in $\mathrm{FEV}_{1}$ is greater than $15 \%$, diagnostic misinterpretation might develop. ${ }^{68}$ CysLT $_{1}$ RA and 5-LOINH do not block upper airway reactions but do prevent or modify bronchospastic reactions during oral aspirin challenges. ${ }^{69,70}$ CysLT $_{1}$ RA shifts target organ responses from lower respiratory tract reactions to mostly upper respiratory tract reactions. ${ }^{69}$

Although not available in the United States, several European centers use bronchial challenges with aspirinlysine. ${ }^{62,71}$ Nizankowska et $\mathrm{al}^{62}$ studied the diagnostic value of bronchial inhalation challenge with L-lysineaspirin in 35 patients with AERD who were suspected of having AERD on the basis of a prior history of NSAID reactions. Thirty-one ( $89 \%$ ) of 35 suspected asthmatic subjects experienced bronchospastic reactions during oral aspirin challenges. In the same patients, $27(77 \%)$ of 35 or, more accurately, 27 (87\%) of 31 known reactors had bronchospastic reactions during inhaled aspirin-lysine challenges.

Aspirin-lysine nasal challenges are also conducted in Europe and have a satisfactory diagnostic capability. ${ }^{63-65,72}$ In a recent study by Micheletto et al, ${ }^{64}$ both asthmatic patients with AERD and aspirin-tolerant asthmatic patients underwent nasal challenges with up to $25 \mathrm{mg}$ of aspirinlysine. Positive nasal responses and increased $\mathrm{uLTE}_{4}$ levels occurred only in the patients with AERD. Despite increased synthesis of leukotrienes (LTs), as measured in $\mathrm{uLTE}_{4}$, none of the patients with AERD experienced asthma attacks during nasal challenges, despite significant nasal responses. The major advantage of intranasal aspirinlysine challenges is avoidance of aspirin-induced bronchospasm. The disadvantages are that pure lower respiratory tract reactors might not be identified, and in some patients with AERD, occluding nasal polyps interfere with nasal flow rates and make it impossible to perform the test. ${ }^{65} \mathrm{In}$ the United States a new diagnostic test for nasal challenge using a dilute solution of ketorolac has recently completed diagnostic trials. ${ }^{73}$ Ketorolac solutions $(8 \mathrm{mg} / \mathrm{mL})$, delivered as a nasal spray in increasing doses every 30 minutes, offer an alternative to aspirin-lysine nasal challenge in the United States because aspirin-lysine has not been approved for use in human subjects by the US Food and Drug Administration.

\section{PATHOGENESIS}

\section{Underlying respiratory disease (Fig 1)}

The pathophysiology of AERD has been partially elucidated. Nasal tissue biopsy specimens from patients with AERD reveal extensive infiltration of eosinophils and degranulated mast cells. ${ }^{74}$ Bronchial biopsy specimens also contain increased numbers of eosinophils and mast cells when compared with biopsy specimens from patients with aspirin-tolerant asthma. ${ }^{75}$ Why the eosinophils and activated mast cells infiltrate the respiratory mucosa in the first place is not clear and difficult to study because any prior inciting events, such as viral infections or exposure to air pollution and cigarette smoke, might have occurred years earlier. Nevertheless, once AERD appears, levels of proinflammatory cytokines synthesized by epithelial cells and activated $\mathrm{T}_{\mathrm{H}} 2$ lymphocytes are found to be increased. These include IL-2, IL-3, IL-4, IL-5, IL-13, GM-CSF, and eotaxin., ${ }^{46-78}$ The cytokines IL-3, IL-4, IL-5, IL-13, and GM-CSF all skew T-lymphocyte responses toward $\mathrm{T}_{\mathrm{H}} 2$, stimulate bone marrow precursor cells, recruit eosinophils, and dramatically increase the lifespan of eosinophils in vitro by inhibiting apoptosis. ${ }^{77}$ IL-5 and GM-CSF are overexpressed in inflammatory cells from mucosal biopsy specimens in patients with AERD. ${ }^{79}$ Eotaxin is also an important chemokine, the primary function of which is recruitment and activation of eosinophils, as well as contribution to tissue damage through induction of reactive oxygen radicals. ${ }^{80} \mathrm{LTC}_{4}, \mathrm{LTD}_{4}$, and $\mathrm{LTE}_{4}$ are also chemotactic for eosinophils. ${ }^{81}$ Mast cells contain $\mathrm{LTA}_{4}$ hydrolase and therefore can covert $\mathrm{LTA}_{4}$ to $\mathrm{LTB}_{4}$, which stimulates bone marrow to form mast cell progenitors and eosinophils. ${ }^{82} \mathrm{LTC}_{4}$ synthase $\left(\mathrm{LTC}_{4} \mathrm{~S}\right)$ converts $\mathrm{LTA}_{4}$ to $\mathrm{LTC}_{4}{ }^{82}$ thus activating this potent pathway. ${ }^{83,84}$ The end result is a striking increase in numbers of eosinophils and mast cells in the respiratory mucosa of patients with AERD. Activated eosinophils can also release cytotoxic molecules (eg, eosinophilic cationic protein, major basic protein, eosinophil-derived neurotoxin, and eosinophil peroxidase), leading to respiratory mucosal inflammation and damage. ${ }^{85}$ Despite identification of the above mechanisms, none are restricted to patients with AERD. In fact, these same inflammatory pathways and patterns can be found in non-aspirin-sensitive asthmatic subjects with nasal polyps and CHES or in allergic asthmatic subjects.

There is clear evidence that most, but not all, patients with AERD synthesize excessive amounts of LTs, even before any exposure to aspirin or NSAIDs. ${ }^{86}$ Higher concentrations of $\mathrm{LTC}_{4}$ and thromboxane $\mathrm{B}_{2}$ were found in bronchoalveolar lavage fluid taken from patients with AERD compared with those seen in samples from control asthmatic subjects and healthy patients. ${ }^{75,87}$ Christie et al ${ }^{88}$ 


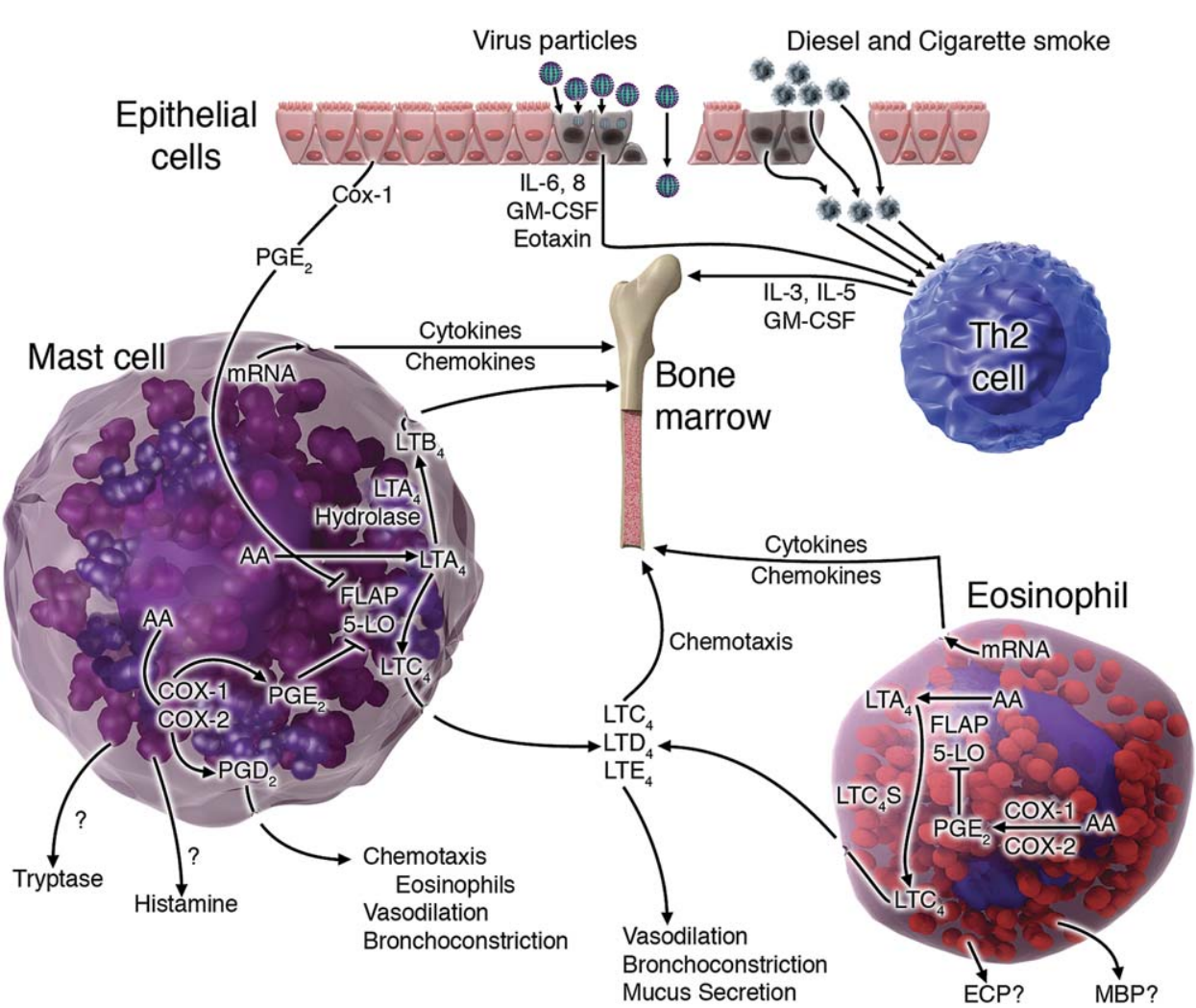

FIG 1. Pathogenesis of AERD. Presumably, a damaging stimulus of respiratory epithelial cells initiates bone marrow formation of mast cell progenitor cells and eosinophils. In AERD these cells are the major contributors to local inflammation. Density and polymorphism of EP2 receptors, as well as cell-activating receptors, are not shown. Chemotaxis of new mast cell progenitor cells and eosinophils from bone marrow perpetuates the disease. $A A$, Arachidonic acid; $E C P$, eosinophil cationic protein; $M B P$, major basic protein.

and Smith et al ${ }^{89}$ were the first to measure increased levels of $\mathrm{LTE}_{4}$ in the urine of patients with AERD before aspirin challenges. Many, but not all, patients with AERD demonstrate overexpression of $\mathrm{LTC}_{4} \mathrm{~S}$ in eosinophils and mast cells in their bronchial biopsy specimens, ${ }^{83}$ and their circulating eosinophils carry more mRNA for $\mathrm{LTC}_{4} \mathrm{~S} .{ }^{90}$ Sanak et $\mathrm{al}^{91}$ discovered genetic polymorphisms of the $\mathrm{LTC}_{4} \mathrm{~S}$ promoter region and identified an increased prevalence of its variant type in Polish patients with aspirininduced asthma, although the same finding also occurred in samples from some healthy individuals. Attempts to find similar patterns in more heterogeneous asthmatic subjects with AERD did not identify an increase in polymorphisms for the flanking region of the gene encoding for $\mathrm{LTC}_{4} \mathrm{~S} .{ }^{92,93}$ Not only is there overproduction of LTs in AERD, but Sousa et $\mathrm{al}^{94}$ demonstrated that in asthmatic subjects with AERD, but not in aspirin-tolerant asthmatic subjects, nasal inflammatory cells expressed more cysLT $T_{1}$ receptors. In patients with AERD, not only is there overproduction of LTs, but more receptors are available to receive these mediators.

Arachidonic acid is synthesized to 5-hydroxyperoxyeicosotetranoic acid by 5-lipoxygenase (5-LO) and 5lipoxygenase-activating protein (FLAP), with synthesis then proceeding down the $\mathrm{LTA}_{4}$ pathway or into the alternative 5-hydroxy-eicosatetraenoic acid (HETE) pathway. Leukocytes and platelets synthesize a microsomal enzyme called 5-hydroxyeicosanoid dehydrogenase, which selectively converts 5-HETE to 5-oxo-6,8,11,14ecosatetraenoic acid (5-OXO-ETE). ${ }^{95}$ Respiratory stress and oxidative stress of polymorphonuclear cells activate synthesis or 5-OXO-ETE, which is a potent chemoattractant for PMNs and eosinophils. Although not specifically investigated in AERD, this proinflammatory mechanism might also be active in AERD, the extent of which is currently unknown.

Just as overproduction of cysLTs is the hallmark of AERD, underproduction of lipoxins correlates with having AERD ${ }^{96}$ Lipoxins are anti-inflammatory derivatives of arachidonic acid and products of lipoxygenation. They require 2 or more lipoxygenase enzymes for biosynthesis (5-LO and 15-LO). They are generated by transcellular cooperation and are functional antagonists of LTs. ${ }^{97-99}$ Therefore diminished capacity to generate lipoxin and 15-epimer lipoxin might contribute to uncontrolled and protracted inflammation in patients with AERD. ${ }^{96,99}$ The possible relationship between this phenomenon and the accumulation of 15-HETE after stimulation with aspirin of peripheral leukocytes from patients with AERD ${ }^{100}$ is interesting but needs further study. 
Prostaglandin (PG) $\mathrm{D}_{2}$, a mast cell-derived prostanoid that is synthesized through the COX-1 and COX-2 pathways, is oversynthesized and secreted in asthmatic subjects with AERD. ${ }^{101} \mathrm{PGD}_{2}$ causes vasodilatation and bronchoconstriction. It is also a potent chemoattractant for eosinophils, operating through prostaglandin $\mathrm{D}_{2}$ receptors $[\mathrm{DP}(2)]$ receptors on eosinophils. ${ }^{102,103}$ Therefore in patients with AERD, not only is there an increase in 5LO products, but certain prostanoids are also proinflammatory and tend to be oversynthesized.

A special role for $\mathrm{PGE}_{2}$ in the pathogenesis of AERD has been suggested. ${ }^{104}$ Peripheral blood macrophage cells (PBMCs) of some patients with AERD undersynthesize $\mathrm{PGE}_{2}$ at baseline. ${ }^{105}$ This places patients with AERD at the disadvantage of lacking sufficient concentrations of cellular or transcellular $\mathrm{PGE}_{2}$ to stabilize mast cells and slow synthesis of LTs. There are 4 receptors for $\mathrm{PGE}_{2}$, E-prostanoid (EP) receptors 1 through 4 . In one study single nucleotide polymorphisms (SNPs) in the promoter region of the gene encoding EP2 were significantly associated with AERD. ${ }^{106}$ Thus decreased transcription of the EP2 receptor for $\mathrm{PGE}_{2}$ might render that subset of patients with AERD unable to efficiently inhibit 5-LO and FLAP, even if they synthesized normal amounts of $\mathrm{PGE}_{2}$. Nasal mucosal biopsy specimens from patients with AERD, when immunostained for all 4 EP receptors, showed a significant reduction in numbers of neutrophils, mast cells, eosinophils, and T cells expressing EP2 receptors but not EP1, EP3, and EP4 receptors. ${ }^{107}$ Another study demonstrated a special role for EP3 receptors in suppressing allergic inflammation and suggested that patients with AERD might depend more on the $\mathrm{PGE}_{2}-\mathrm{EP} 3$ receptor pathway than do aspirin-tolerant asthmatic subjects and healthy subjects. ${ }^{108}$ Any of these discovered defects, under synthesis of $\mathrm{PGE}_{2}$ or its EP2 or EP3 receptors, diminishes the blocking capabilities of $\mathrm{PGE}_{2}$ on 5-LO and FLAP or an inhibitory effect on mast cells. ${ }^{109}$

Recently, several authors addressed the problem of genetic polymorphism. ${ }^{110-114}$ The most comprehensive study of genetic associations with AERD was published by Jinnai et al. ${ }^{106}$ Using 370 SNPs from 63 candidate genes, almost 200 patients with AERD were compared with aspirin-tolerant asthmatic subjects and control subjects. A gene coding for EP receptor 2 was the only one significantly associated with AERD. The investigators, using 24 SNPs' haplotypes, demonstrated that a region located $11 \mathrm{~kb}$ upstream from the translation start of the gene had the best correlation with the AERD phenotype. A particular allele, $-12813 \mathrm{~A}$ instead of $\mathrm{G}$, in vitro had diminished transcriptional activity when stimulated by IL-4 through the IL-4 receptor-signal transducer and activator of transcription 6 pathway. This finding recaptured attention when Ying et $\mathrm{al}^{107}$ demonstrated that inflammatory cells infiltrating the nasal mucosa of patients with AERD were deficient in EP2.

Nearly a decade after the initial description of an association between the HLA DPB 1 locus and AERD, ${ }^{112}$ these data were replicated by Choi et al. ${ }^{111}$ Despite a quite different ethnicity (Polish vs Korean), the same allele,
DPB $1 * 0301$, was overrepresented in aspirin-hypersensitive asthmatic subjects. Thus an adaptive immune response to MHC class II antigens has probably occurred to mediate at least a step in the development of AERD.

Attempting to put this whole picture into perspective, many of the inflammatory pathways described above are also found in patients who have no reactions to aspirin and other NSAIDs. However, one theme that runs through most studies is that in patients with AERD, measurements of cytokines, eicosanoid mediators ( $\mathrm{uLTE}_{4}$ and $\mathrm{PGD}_{2}$ ), and cysLT $\mathrm{T}_{1}$ receptors tend to group in the high end of most study results. Yet clearly separating individual asthmatic subjects with AERD from aspirintolerant asthmatic subjects cannot be accomplished on the basis of their inflammatory profiles, including their $\mathrm{uLTE}_{4}$ levels, because of considerable overlap between patients with AERD and aspirin-tolerant asthmatic subjects. To make matters more difficult, patients with AERD can be mild, moderate, or severe in their clinical disease presentation and their inflammatory profiles. ${ }^{86}$ Despite these comments, a pattern is emerging in which many defects in either overstimulation of inflammation or underproduction of countermeasures, especially in the eicosanoid family, is found in patients with AERD. Furthermore, a single genetic defect or promoter gene that accounts for all patients with AERD has not been discovered. Rather, some patients with AERD are upregulating $\mathrm{LTC}_{4} \mathrm{~S}$, others are upregulating cysLT ${ }_{1}$ receptors, and still others are oversynthesizing specific cytokines. At the opposite end of the equation, some patients with AERD are undersynthesizing lipoxins, $\mathrm{PGE}_{2}$, or EP2 or EP3 receptors. These facts would fit a theory in which multiple divergences in inflammatory pathways could occur in different patients with AERD, yet rendering all patients vulnerable to aspirin.

\section{Aspirin- and NSAID-induced hypersensitivity reactions (Fig 2)}

In patients with AERD, acute respiratory reactions induced by aspirin or NSAIDs encompass all the features of immediate IgE-mediated hypersensitivity reactions, yet such a mechanism has never been demonstrated. ${ }^{54}$ This fact is logical when one considers that all structurally distinct NSAIDs that inhibit COX-1 can cause respiratory tract reactions in all patients with AERD on first exposure to the new NSAID. ${ }^{27,28,115}$ Thus drug hapten-antibody recognition cannot be responsible for these reactions. ${ }^{3}$

When patients with AERD undergo aspirin challenges, very substantial increases in $\mathrm{ULTE}_{4}$ levels and decreases in COX-1 products are recorded during bronchospastic reactions ${ }^{86,88,116}$ or nasal responses. ${ }^{64}$ Increases in $\mathrm{LTC}_{4}$ and histamine levels in both nasal ${ }^{117-119}$ and bronchial lavage $^{75}$ fluid after oral aspirin challenges in patients with AERD, but not aspirin-tolerant control subjects, have also been measured. As shown in Fig 2, during aspirin-induced respiratory reactions, mast cells release histamine and tryptase and synthesize prostanoids $\left(\mathrm{PGD}_{2}\right)$ and LTs, and eosinophils secrete toxic molecules and synthesize LTs. 109,120 


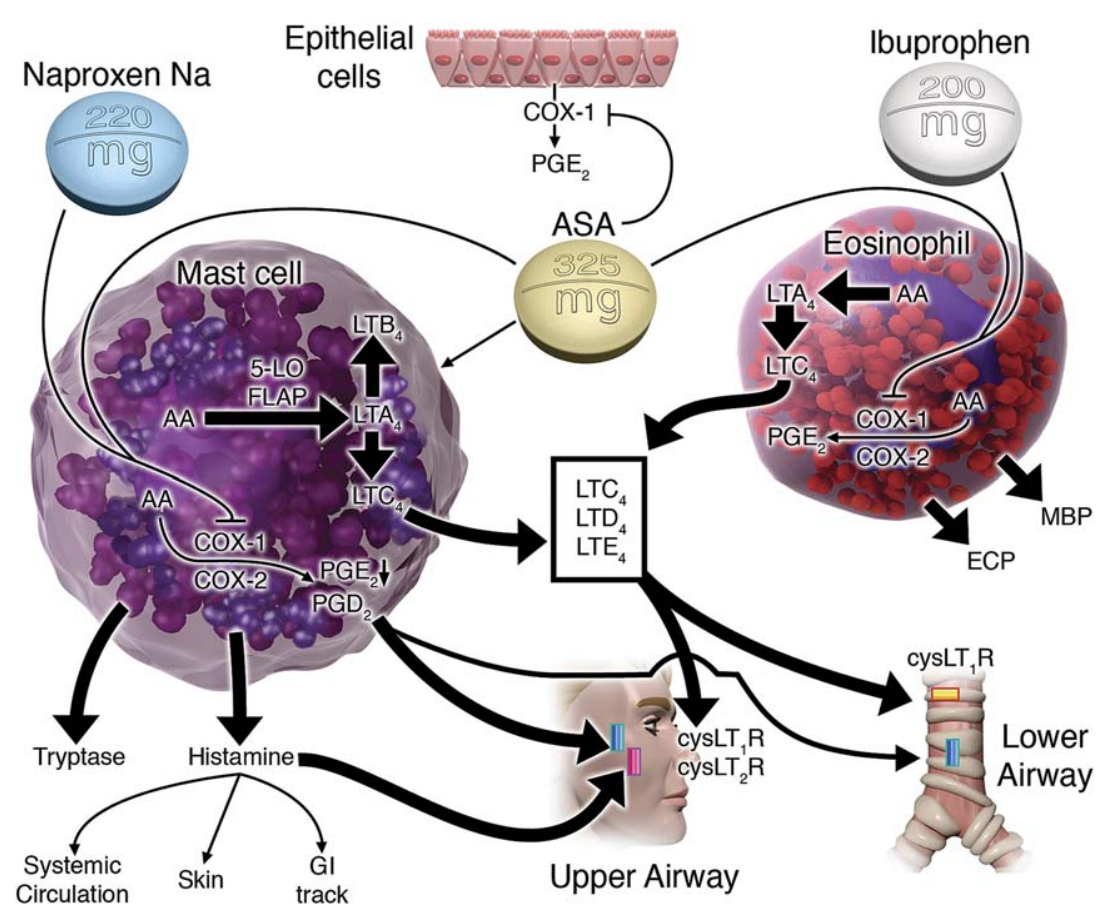

FIG 2. Aspirin or NSAIDs induced respiratory reactions. Aspirin and NSAIDs inhibit COX-1, thus depriving mast cells and eosinophils of $\mathrm{PGE}_{2}$ to block the ongoing synthesis of $L T s$. Alteration in function of $\mathrm{PGE}_{2}$ receptors (particularly EP2) might contribute to the inability of $\mathrm{PGE}_{2}$ to sustain the blockade. From mast cells, $\mathrm{PGD}_{2}$ is oversynthesized, and histamine and tryptase are released during reactions. Eosinophil cationic protein $(E C P)$ and major basic protein $(M B P)$ are released from eosinophils. $A A$, Arachidonic acid.

Over the years, it has become clear that excessive synthesis of LTs in patients with AERD undergoing respiratory reactions to NSAIDs or aspirin is secondary to competitive inhibition or disabling of COX-1 enzymes (Fig 2). ${ }^{120} \mathrm{COX}-1$ is a constitutively expressed enzyme that is present in most mammalian cells, including respiratory and gastrointestinal epithelial cells, as well as inflammatory cells. COX-2, by contrast, is only expressed in inflammatory cells and is an inducible enzyme that is highly upregulated by proinflammatory mediators, such as cytokines, growth factors, and molecules coming from tissue injury. ${ }^{120}$ When COX-1 is inhibited by aspirin or cross-reacting NSAIDs, there is a rapid decrease in the synthesis of COX-1 products, including $\mathrm{PGE}_{2}$. In healthy individuals and, to a lesser extent, patients with AERD, $\mathrm{PGE}_{2}$ inhibits 5-LO and FLAP enzymes that otherwise would generate potent proinflammatory mediators, such as LTC, LTD, and $\mathrm{LTE}_{4}$ and $\mathrm{LTB}_{4}$.

When COX-1 enzymes are inhibited by aspirin and NSAIDs, the braking effects of $\mathrm{PGE}_{2}$ are further reduced or disappear, and 5-LO is unopposed, allowing large increases in synthesis of LTs. ${ }^{104}$ Reduced $\mathrm{PGE}_{2}$ synthesis also results in decreased mast cell stability and increased release of histamine and tryptase. ${ }^{109}$ During oral aspirin challenges, when patients with AERD were pretreated with inhaled $\mathrm{PGE}_{2}$, they did not experience respiratory reactions, and uLTE 4 levels did not increase. ${ }^{121,122}$ The failure of COX-2 inhibitors to cross-react in patients with AERD is further evidence that COX-2 enzymes do not synthesize enough $\mathrm{PGE}_{2}$ to make a difference in the loss of $\mathrm{PGE}_{2}$. This should not be surprising because the small numbers of inflammatory cells synthesizing $\mathrm{PGE}_{2}$, when compared with the millions of cells expressing constitutive COX-1, all epithelial and endothelial cells of the respiratory tract, makes inhibition of COX-2 a minor event from the standpoint of available $\mathrm{PGE}_{2}$. Furthermore, expression of COX-2 is diminished and its activity is reduced in patients with AERD. ${ }^{123,124}$ The fact that meloxicam does not cross-react with aspirin in AERD with low doses (at which COX-2 is inhibited) but does crossreact at high doses (at which COX-1 is inhibited) provides further evidence that COX-1 inhibition is the key event in the induction of aspirin/NSAID-induced respiratory reactions. Finally, the defect of undersynthesizing $\mathrm{PGE}_{2}$ or decreased transcription of EP2 receptors for $\mathrm{PGE}_{2}$ might well render patients with AERD preferentially unable to inhibit 5-LO and FLAP when challenged with aspirin or NSAIDs. This area of research is critical because explaining why inhibition of COX-1 and COX-2 in healthy subjects or aspirin-tolerant asthmatic subjects does not lead to the same respiratory reactions hinges on as-yet-undiscovered fundamental defects unique to patients with AERD.

In addition to increased synthesis of LTs, most patients with AERD also have increased expression of cysLT receptors on their inflammatory cells. ${ }^{94}$ Thus not only is there an absence of braking effects by $\mathrm{PGE}_{2}$ and a surge of new LT molecules, but the number of cysLT $T_{1}$ receptors on target cells 


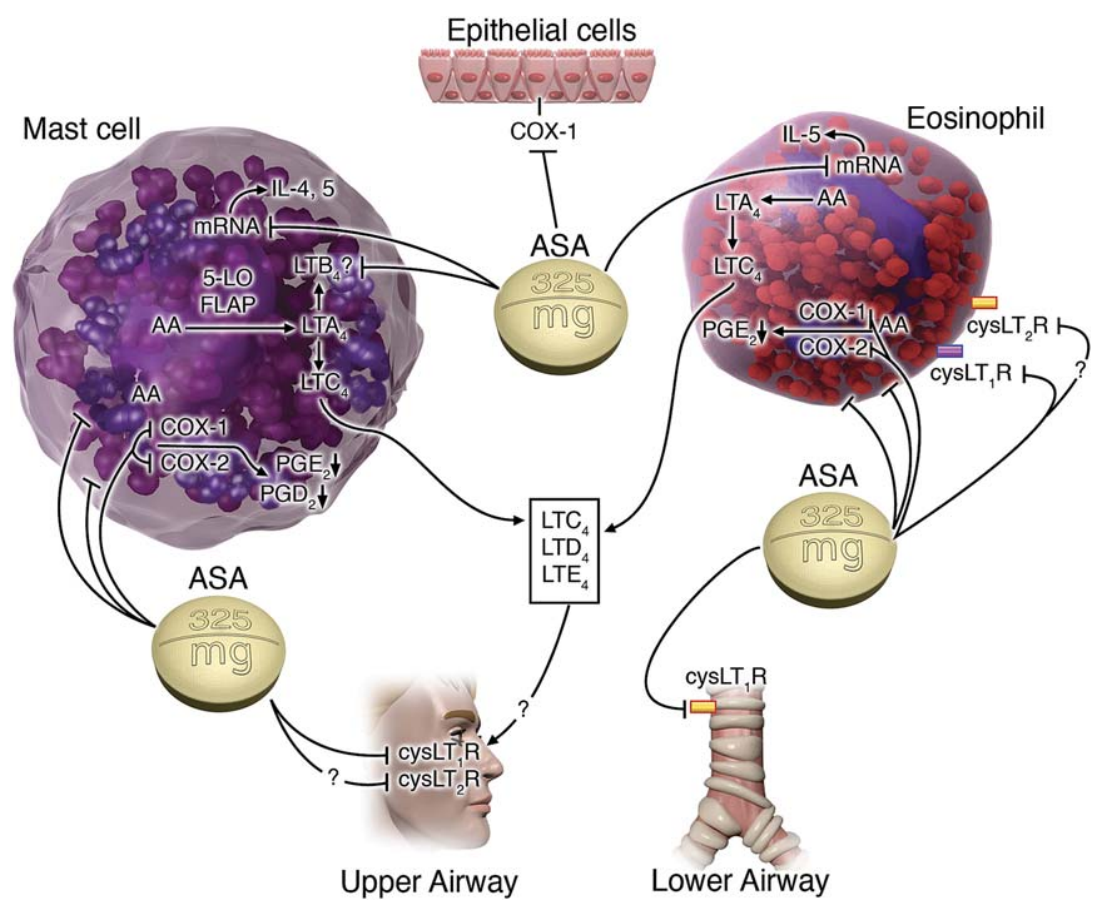

FIG 3. Aspirin desensitization. After aspirin disables COX-1 and COX-2, inflammatory cells are unable to synthesize prostanoids, including the proinflammatory $\mathrm{PGD}_{2}$ and the anti-inflammatory $\mathrm{PGE}_{2}$. Histamine and tryptase are no longer released from mast cells. Eosinophils stop releasing toxic molecules. CysLT receptors are underexpressed after aspirin treatment, and it is likely that intracellular transcription factors are also inhibited by aspirin.

are also increased. This tips the equation toward a pronounced increase in end-organ responses to LTs. ${ }^{125}$

LTs are not the only mediators released or synthesized during aspirin-induced respiratory reactions. Nasal secretions obtained during aspirin-induced reactions contained increased concentrations of histamine, tryptase, $\mathrm{LTB}_{4}$, $\mathrm{LTC}_{4}$, and $\mathrm{PGD}_{2}$ and decreased concentrations of $\mathrm{PGE}_{2}$. ${ }^{117-119,126}$ The same is true for bronchial secretions during aspirin-lysine-induced lower respiratory tract reactions. ${ }^{75} \mathrm{PGD}_{2}$ metabolites increase in serum samples during aspirin-induced respiratory reactions. ${ }^{101}$ During oral aspirin challenges, a minority of patients with AERD have extrapulmonary reactions. ${ }^{54}$ In such patients histamine and tryptase levels were found to be increased in the systemic circulation. ${ }^{127}$

\section{Aspirin desensitization (Fig 3)}

Aspirin desensitization is one of the most consistent and least understood features of aspirin and asthma. Almost all patients with AERD can be desensitized to aspirin and then take aspirin indefinitely to maintain their desensitized state. During aspirin desensitization, $\mathrm{uLTE}_{4}$ levels returned to baseline, ${ }^{86}$ and cysLT $T_{1}$ receptor levels decreased significantly. ${ }^{94}$ At 2 weeks after daily treatment with aspirin, $650 \mathrm{mg}$ twice daily, $\mathrm{LTB}_{4}$ synthesis by peripheral monocytes also decreased significantly in patients with AERD. ${ }^{128}$ A reduction in synthesis of $\mathrm{LTB}_{4}$ would be therapeutically useful in reducing chemotaxis of eosinophils and polymorphonuclear leukocytes, as well as mast cell progenitors. $\mathrm{LTC}_{4}$ and histamine disappeared in nasal secretions at the onset of aspirin desensitization. ${ }^{117}$ Biochemically, we can measure specific changes that downregulate inflammation and accompany aspirin desensitization. However, why aspirin desensitization occurs in the first place continues to be a challenging question.

\section{TREATMENT}

\section{Avoidance of aspirin and NSAIDs and treatment of reactions}

Education of patients regarding complete avoidance of COX-1 inhibitors is important. In particular, asthmatic patients need to be vigilant when ingesting over-thecounter remedies that might include aspirin or NSAIDs (eg, Alka Seltzer Plus Flu, which contains $500 \mathrm{mg}$ of aspirin). In addition, appropriate flagging of charts and communication among health care professionals, including physician and pharmacy computers, is vital in preventing future inappropriate administration of cross-reacting NSAIDs in those patients with AERD already given a diagnosis. We are not advocating universal avoidance of NSAIDs for all asthmatic patients. Such a position denies $80 \%$ to $90 \%$ of asthmatic subjects access to these important medications. However, use of COX-2 inhibitors, extra care, and thoughtful use of first-dose ingestion of COX1 inhibitors in physicians' offices might prevent some inadvertent bronchospastic catastrophes. The major 
danger of death from asthma in AERD is the first NSAIDinduced reaction, particularly if this occurs far from a medical facility.

Depending on the severity, acute respiratory reactions caused by accidental aspirin or NSAID ingestion are treated with inhaled $\beta$-agonists by using multiple dosing (5 inhalations, wait 5 minutes, and then keep repeating inhalation treatments), antihistamines, systemic corticosteroids, and, if systemic histamine release is present, intramuscular epinephrine. Patients who experience laryngospasm respond rapidly to racemic epinephrine administered by means of nebulization. Some patients will need more intense medical attention, including admission to the intensive care unit, intubation, and mechanical ventilation.

\section{Treatment of the underlying respiratory tract disease}

Long-term control of both upper and lower airway inflammation is the goal of treatment. High doses of intranasal steroids are helpful in reducing inflammation and retarding nasal polyp formation in some patients. ${ }^{129}$ During acute bacterial sinus infections, extended courses of broad-spectrum antibiotics are frequently required. ${ }^{130}$ Often patients will also respond to a 2- to 3-week burst of systemic corticosteroids to aid in shrinking nasal polyps and reestablishing temporary sinus drainage. A subset of patients will gradually require continuous systemic corticosteroids. In a review of 300 patients with AERD, systemic corticosteroids were used as short courses in 134 (45\%), on a daily basis in 95 (32\%), and not at all in 71 (23\%). ${ }^{18}$ Unfortunately, as daily or frequent bursts of systemic doses of corticosteroids escalate, significant adverse side effects also begin to accumulate.

Zileuton (a 5-LOINH) and montelukast (a cysLT $\mathrm{T}_{1} \mathrm{RA}$ ), are commonly used in patients with AERD, with variable success. Dahlen et $\mathrm{al}^{131,132}$ studied the effect of zileuton on the clinical course of 40 patients with AERD in a double-blind placebo-controlled treatment trial and demonstrated efficacy. Montelukast has also been studied in a double-blind placebo-controlled treatment trial in 80 patients with AERD, in which efficacy was also demonstrated. ${ }^{133} \mathrm{CysLT}_{1} \mathrm{RA}$ treatment success is distinctly better in the carriers of the variant $\mathrm{C}$ allele of $\mathrm{LTC}_{4} \mathrm{~S}^{134-137}$ and in individuals with the HLA-DPB $1 * 0301$ marker. ${ }^{138}$ In our experience LT-modifier drugs are generally helpful as adjunctive therapy. Particularly in view of the fact that AERD is largely the result of overproduction of cysLTs, the addition of a 5-LOINH or a cysLT ${ }_{1}$ RA to a baseline of topical corticosteroids is now fairly routine treatment for AERD. The use of both zileuton and a cysLT $T_{1} R A$ has never been formally studied in patients with AERD but is used by clinicians with anecdotal success.

In patients with AERD who are also atopic, treatment of underlying allergic inflammation should also be maximized. Allergen avoidance, antihistamines, immunotherapy, and anti-IgE treatment should be strongly considered as adjunctive treatment in patients with AERD with this concomitant disorder. It does not make any sense to ignore a concomitant disease, such as allergic rhinitis and asthma, and conclude that AERD by itself is the only important mechanism that is driving eosinophilic inflammation in patients with both AERD and allergic respiratory disease. In a study of 300 patients with AERD, two thirds had positive wheal-and-flare skin test responses to relevant allergens. ${ }^{18}$

When maximal medical management of nasal polyposis has failed, which is common, referral to a competent otolaryngologist should be initiated. In fact, many patients begin their medical journey with an otolaryngologist because nasal polyps and anosmia are an early and devastating manifestation of the disease. Nasal polypectomies, resection of eosinophilic inflammatory tissue, and widening of sinus ostia can be performed to help reestablish proper drainage. In addition, at the time of surgery, specimens can be sent for cultures and pathologic investigation, which can be helpful in choosing appropriate antibiotic or antifungal therapy. McFadden et $\mathrm{al}^{139}$ followed 22 patients with AERD who underwent endoscopic sinus surgery for 1 year. Patients showed improvement in pulmonary function testing, need for topical and systemic corticosteroids, and quality-of-life measures. Kennedy ${ }^{140}$ reported that patients with AERD have the same long-term, postsurgical outcomes as aspirin-tolerant patients, if they have the same degree of mucosal disease. However, patients with AERD as a group tend to have a larger burden of polypoid tissue, and postsurgical regrowth of polypoid tissue remains a significant problem. ${ }^{141}$ On average, reoperation for nasal polyps is required every 3 years in patients with AERD. ${ }^{18,142}$

\section{Aspirin desensitization}

Aspirin desensitization is an effective yet underused means of treating patients with AERD. Almost all patients with AERD can be desensitized to aspirin. ${ }^{143}$ Once desensitized and maintained with daily ingestion of aspirin, patients not only enjoy significant improvement in both upper and lower respiratory symptoms but can also ingest any of the cross-reacting NSAIDs without acute respiratory reactions. ${ }^{144,145}$ Four long-term studies of patients who underwent aspirin desensitization followed by daily aspirin ingestion have demonstrated efficacy in reducing upper airway congestion and nasal polyp formation and improving lower airway asthma control. ${ }^{142,145-147}$ One study involved 172 patients desensitized between 1995 and 2000 and treated with aspirin, $650 \mathrm{mg}$ twice daily, for 1 to 5 years. ${ }^{145}$ Significant reductions in sinus infections and number of rescue oral steroid courses were observed, as well as improvements in anosmia, rhinitis, and asthma symptom scores. Of the 126 patients who completed a year or more of aspirin treatment, $87 \%$ experienced good or excellent improvement in their clinical courses. In another study patients began to enjoy improvement in upper airway congestion as early as 4 weeks after starting aspirin treatment. ${ }^{144}$

Aspirin desensitization should be considered as add-on treatment in patients with uncontrolled upper and lower respiratory symptoms, patients requiring multiple polypectomies and/or sinus operations, patients requiring unacceptably high intermittent or chronic systemic 
corticosteroids, and patients requiring aspirin/NSAIDs for treatment of other diseases, such as prophylaxis for coronary artery disease or postcoronary stent protection against thrombosis and acute myocardial infarction.

Performing aspirin challenges followed by desensitization is relatively safe. ${ }^{147}$ We are not aware of any published or unpublished reports of deaths during controlled oral aspirin challenges. The risk of aspirin-induced asthma can be significantly reduced by using pretreatment with cysLT ${ }_{1}$ RAs. ${ }^{69,70}$ Because the reaction severity is ASA dose dependent, the degree of respiratory reactions is almost always smaller than the original reported aspirin/NSAIDinduced reaction with full therapeutic doses of drug.

Chronic aspirin therapy can result in well-known adverse side effects in a minority of patients. In the most recent Scripps Clinic study, 24 (14\%) of 172 patients had to discontinue aspirin therapy because of side effects: 14 had epigastric pain, 2 had gastrointestinal bleeding, 2 had bleeding from the nose and ear, and 6 had aspirin-induced urticaria. ${ }^{145}$ Patients with a prior history of gastritis, gastroduodenal ulcers, and gastroesophageal reflux might be at higher risk for development of aspirin-induced gastritis, but no prospective study of such patients has been conducted.

\section{CONCLUSION}

AERD is a distinct clinical entity that is characterized by aspirin-induced respiratory reactions, asthma, nasal polyposis, and CHES. If not recognized and treated appropriately, AERD has the potential to cause significant morbidity and even mortality, particularly when full doses of aspirin or NSAIDs are ingested away from an acutecare medical facility. Patients must be educated regarding avoidance of aspirin and cross-reacting COX-1 inhibitors to prevent potential life-threatening asthma exacerbations. Treatment of nasal polyp and sinus disease is also essential to effectively control asthma, as well as to significantly prevent secondary respiratory tract infections and improve patients' quality of life. Aspirin desensitization should be considered as add-on treatment for AERD in many patients. Hopefully, etoricoxib, parecoxib, and lumiracoxib, new selective COX-2 inhibitors available in Europe and elsewhere, will find their way into the US market over the next few years. Further pharmacologic advances, such as a new 5-LO or FLAP inhibitor with improved pharmacokinetics might also be on the horizon.

\section{REFERENCES}

1. Widal MF, Abrami P, Lermeyez J. Anaphylaxie et idiosyncrasie. Presse Med 1922;30:189-92.

2. Samter M, Beers RF. Concerning the nature of the intolerance to aspirin. J Allergy 1967;40:281-93.

3. Samter M, Beers R Jr. Intolerance to aspirin: clinical studies and consideration of its pathogenesis. Ann Intern Med 1968;68:975-83.

4. Borish L. Sinusitis and asthma: entering the realm of evidence-based medicine. J Allergy Clin Immunol 2002;109:606-7.

5. Stevenson D, Sanchez-Borges M, Szczeklik A. Classification of allergic and pseudoallergic reactions to drugs that inhibit cyclooxygenase enzymes. Ann Allergy Asthma Immunol 2001;87:177-80.
6. Johannessen SGO, Bieber T, Dahl R, Friedmann PS, Lanier BO Lockey RF, et al. Revised nomenclature for allergy for global use: report of the Nomenclature Review Committee of the World Allergy Organization, Oct 2003. J Allergy Clin Immunol 2004;113:832-6.

7. Jenkins C, Costello J, Hodge L. Systematic review of prevalence of aspirin-induced asthma and its implications for clinical practice. BMJ 2004;328:434-7

8. Hedman J, Kaprio J, Poussa T, Nieminen MM. Prevalence of asthma, aspirin intolerance, nasal polyps and chronic obstructive pulmonary disease in a population-based study. Int J Epidemiol 1999; 28:717-22.

9. Kasper L, Sladek K, Duplaga M, Bochenek G, Liebhart J, Gladysz U, et al. Prevalence of asthma with aspirin hypersensitivity in the adult population of Poland. Allergy 2003;58:1064-6.

10. Vally H, Taylor M, Thompson PJ. The prevalence of aspirin intolerant asthma in Australian asthmatic patients. Thorax 2002;57:569-74.

11. Delaney JC. The diagnosis of aspirin idiosyncrasy by analgesic challenge. Clin Allergy 1976;6:177-81.

12. McDonald J, Mathison DA, Stevenson DD. Aspirin intolerance in asthma-detection by challenge. J Allergy Clin Immunol 1972;50:198-207.

13. Spector SL, Wangaard CH, Farr RS. Aspirin and concomitant idiosyncrasies in adult asthmatic patients. J Allergy Clin Immunol 1979;64: 500-6.

14. Stevenson DD, Mathison D, Tan E, Vaughn J. A study of provoking factors in bronchial asthma. Arch Intern Med 1975;135:777-83.

15. Weber RW, Hoffman M, Raine DA, Nelson HS. Incidence of bronchoconstriction due to aspirin, azo dyes, non-azo dyes, and preservatives in a population of perennial asthmatics. J Allergy Clin Immunol 1979;64: 32-7.

16. Rachelefsky GS, Coulson A, Siegel SC, Stiehm ER. Aspirin intolerance in chronic childhood asthma: detection by oral challenge. Pediatrics 1975;56:443-8.

17. Pleskow WW, Stevenson DD, Mathison DA, Simon RA, Schatz M, Zieger RS. Aspirin-sensitive rhinosinusitis/asthma: spectrum of adverse reactions to aspirin. J Allergy Clin Immunol 1983;71:574-9.

18. Berges-Gimeno M, Simon RA, Stevenson DD. The natural history and clinical characteristics of aspirin exacerbated respiratory disease. Ann Allergy Asthma Immunol 2002;89:474-8.

19. Szczeklik A, Nizankowska E, Duplaga M. Natural history of aspirininduced asthma. AIANE Investigators. European Network on AspirinInduced Asthma. Eur Respir J 2000;16:432-6.

20. Szczeklik A. Aspirin-induced asthma as a viral disease. Clin Allergy 1988;18:15-20.

21. Diaz-Sanchez D, Garcia MP, Wang M, Jyrala M, Saxson A. Nasal challenge with diesel exhaust particles can induce sensitization to a neoallergen in mice. J Allergy Clin Immunol 1999;104:1183-8.

22. Finkelman FD, Yang M, Orekhova T, Clyne E, Bernstein L, Whiteku $\mathrm{M}$, et al. Diesel exhaust particles suppress in vivo IFN-gamma production by inhibiting cytokine effects on NK and NKT cells. J Immunol 2004; 172:3808-13

23. Heo Y, Saxson A, Hankinson O. Effect of diesel exhaust particles and their components on the allergen-specific $\operatorname{IgE}$ and $\operatorname{IgG} 1$ response in mice. Toxicology 2001;159:143-58.

24. Johnstone RAW, Plimmer J. The chemical constituents of tobacco and tobacco smoke. Chem Rev 1959;59:885-936.

25. Wjst M, Heinrich J, Liu P, Dold S, Wassmer G, Merkel G, et al. Indoor factors and serum IgE levels in children. Allergy 1994;49:766-71.

26. Stevenson D, Simon RR, Zuraw BL. Sensitivity to aspirin and NSAIDs In: Adkinson NJ, Yunginger JW, Busse WW, Bochner BS, Holgate ST, Simon FE, editors. Allergy: principles and practice. 6th ed. Philadelphia: CV Mosby and Co; 2003. p. 1695-710.

27. Szczeklik A, Gryglewski RJ, Czerniawska-Mysik G. Clinical pattern of hypersensitivity to nonsteroidal anti-inflammatory drugs and their pathogenesis. J Allergy Clin Immunol 1977;60:276-84

28. Vanselow NA, Smith JR. Bronchial asthma induced by indomethacin. Ann Intern Med 1967;66:568-73.

29. Szczeklik A, Gryglewski RJ, Czerniawska-Mysik G. Relationship of inhibition of prostaglandin biosynthesis by analgesics to asthma attacks in aspirin-sensitive patients. BMJ 1975;1:67-9.

30. Mathison DA, Stevenson DD. Hypersensitivity to non-steroidal anti-inflammatory drugs: indications and methods for oral challenge. J Allergy Clin Immunol 1979;64:669-74. 
31. Woessner K. Cross-reacting drugs and chemicals. Clin Rev Allergy Immunol 2003;24:149-58.

32. Settipane RA, Stevenson DD. Cross sensitivity with acetaminophen in aspirin sensitive asthmatics. J Allergy Clin Immunol 1989;84:26-33.

33. Stevenson DD, Hougham A, Schrank P, Goldlust B, Wilson R. Disalcid cross-sensitivity in aspirin sensitive asthmatics. J Allergy Clin Immunol 1990;86:749-58.

34. Asero R. Multiple sensitivities to NSAIDs. Allergy 2000;55:893-4.

35. Quaratino D, Romano A, Di Fonso M, Papa G, Perrone MR, D'Anbrosia FP, et al. Tolerability of meloxicam in patients with histories of adverse reactions to nonsteroidal anti-inflammatory drugs. Ann Allergy Asthma Immunol 2000;84:613-7.

36. Bavbek S, Celik G, Ediger D, Mungan D, Demirel YS, Misirligil Z. The use of nimesulide in patients with acetylsalicylic acid and nonsteroidal anti-inflammatory drug intolerance. J Asthma 1999;36:657-63.

37. Vaghi A. Tolerance of meloxicam in aspirin-sensitive asthmatics. Am J Respir Crit Care Med 1998;157:715.

38. Bavbek S, Celik G, Ozer F, Mungan D, Misirligil Z. Safety of selective COX-2 inhibitors in aspirin/NSAID intolerant patients: comparison of nimesulide, meloxicam and rofecoxib. J Asthma 2004;41:67-75.

39. Stevenson DD, Simon RA. Lack of cross-reactivity between rofecoxib and aspirin in aspirin sensitive asthmatic patients. J Allergy Clin Immunol 2001;108:47-51

40. Martin-Garcia C, Hinojosa M, Berges P. Safety of a cyclooxygenase-2 inhibitor in patients with aspirin- sensitive asthma(*). Chest 2002;121: 1812-7.

41. Szczeklik A, Nizankowska E, Bochenek G, Nagraba K, Mejza F, Swierczynska M. Safety of a specific COX-2 inhibitor in aspirininduced asthma. Clin Exp Allergy 2001;31:219-25.

42. Yoshida S, Ishizaki Y, Onuma K, Shoji T, Nakagawa H, Amayasu H. Selective cyclo-oxygenase 2 inhibitor in patients with aspirin-induced asthma. J Allergy Clin Immunol 2000;106:1201-2.

43. Woessner KM, Simon RA, Stevenson DD. The safety of celecoxib in aspirin exacerbated respiratory disease. Arthritis Rheum 2002;46:2201-6.

44. Gyllfors BG, Overholt J, Drupka D, Kumlin M, Sheller J, Nizankowska $\mathrm{E}$, et al. Biochemical and clinical evidence that aspirin-intolerant asthmatic subjects tolerate the cyclooxygenase 2-selective analgetic drug celecoxib. J Allergy Clin Immunol 2003;111:1116-21.

45. Vola M, Quaratino D, Volpetti S, Gaeta F, Romano A. Parecoxib tolerability in patients with hypersensitivity to nonsteroidal anti-inflammatory drugs. J Allergy Clin Immunol 2006;117:1189-90.

46. Rordorf CM, Choi I, Marshall P, Mangold JP. Clinical and pharmacology of lumiracoxib: a selective cyclo-oxygenase-2 inhibitor. Clin Pharmacokinet 2005;44:1247-66

47. Baldassarre S, Schandene L, Choufani G, Michils A. Asthma attacks induced by low doses of celecoxib, aspirin and acetaminophen. J Allergy Clin Immunol 2006;117:215-7.

48. Woessner KW, Simon RA, Stevenson DD. Safety of high-dose rofecoxib in patients with aspirin-exacerbated respiratory disease. Ann Allergy Asthma Immunol 2004;93:1-6.

49. Mastalerz L, Sanak M, Gawlewicz A, Gielicz A, Faber J, Szczeklik A. Different eicosanaoid profile of the hypersensitivity reactions triggered by aspirin and celecoxib in a patient with sinusitis and asthma. J Allergy Clin Immunol 2006;118:957-8

50. Passero M. Cyclo-oxygenase-2 inhibitors in aspirin sensitive asthma. Chest 2003;123:2155-6.

51. Morias-Almeida Marinho S, Rosa S, Rosado-Pinto JE. Multiple drug intolerance, including etoricoxib. Allergy 2006;61:144-5.

52. Hawley C. COX-2 inhibitors. Lancet 1999;353:307-14.

53. Warner TD, Guiliano F, Vojnovic I, Bukasa A, Mitchell JA, Vane JR. Nonsteroidal drug selectivity for cyco-oxygenase-1 rather than cyclooxygenase- 2 are associated with human gastrointestinal toxicity: a full in vitro analysis. Proc Natl Acad Sci U S A 1999;96:9666.

54. Stevenson DD. Anaphylactic and anaphylactoid reactions to aspirin and nonsteroidal anti-inflammatory drugs. Immunol Allergy Clin North Am 2001;21:745-68.

55. Levy MB, Fink JN. Anaphylaxis to celecoxib. Ann Allergy Asthma Immunol 2001;87:72-3

56. Kaur C, Sakar R, Kanwar AJ. Fixed drug eruption to rofecoxib with cross-reactivity to sulfonamides. Dermatology 2001;203:351.

57. Brune K, Hines B. The discovery and development of anti-inflammatory drugs. Arthritis Rheum 2004;50:2391-9.
58. Gamboa P, Sanz M, Caballero MR, Urrutia I, Antepara I, Esparza R, et al. The flow-cytometric determination of basophil activation by aspirin and other non-steroidal anti-inflammatory drugs (NSAIDs) is useful for in vitro diagnosis of the NSAID hypersensitivity syndrome. Clin Exp Allergy 2004;34:1448-57.

59. Stevenson DD. Oral challenges to detect aspirin and sulfite sensitivity in asthma. New England Regional Allergy Proceedings 1988;9:135-42.

60. Dahlen B, Zetterstrom O. Comparison of bronchial and per oral provocation with aspirin in aspirin-sensitive asthmatics. Eur Respir J 1990;3: 527-34.

61. Melillo G, Podovano A, Cocco G, Masi C. Dosimeter inhalation test with lysine acetylsalicylate for the detection of aspirin-induced asthma. Ann Allergy 1993;71:61-5.

62. Nizankowska E, Bestynska-Krypel A, Cmiel A, Szczeklik A. Oral and bronchial provocation tests with aspirin for diagnosis of aspirin-induced asthma. Eur Respir J 2000;15:863-9.

63. Alonso-Llamazares A, Martinez-Cocera C, Dominguez-Ortega J, Robledo-Echarren T, Cimarra-Alvarez M, Mesa del Castillo M. Nasal provocation test (NPT) with aspirin: a sensitive and safe method to diagnose aspirin-induced asthma. Allergy 2002;57:632-5.

64. Micheletto C, Tognella S, Visconti M, Trevisian F, Dal Negro RW. Changes in urinary LTE4 and nasal function following nasal provocation tests with ASA-tolerant and -intolerant asthmatics. Respir Med 2006; May 4 [Epub ahead of print].

65. Milewski M, Mastalerz L, Nizankowska E, Szczeklik A. Nasal provocation test with lysine-aspirin for diagnosis of aspirin-sensitive asthma. J Allergy Clin Immunol 1998;101:581-6.

66. Mita H, Endoh S, Kudoh M, Akiyama K. Possible involvement of mast-cell activation in aspirin provocation of aspirin-induced asthma. Allergy 2001;56:1061-7.

67. Szczeklik A, Serwonska M. Inhibition of idiosyncratic reactions to aspirin in asthmatic patients by clemastine. Thorax 1979;34:654-8.

68. Stevenson DD. Oral challenge, aspirin, NSAID, tartrazine, and sulfites. N Engl Regional Allergy Proc 1984;5:111-20.

69. Berges-Gimeno M, Simon RA, Stevenson DD. The effect of leukotriene modifier drugs on asa-induced asthma and rhinitis reactions. Clin Exp Allergy 2002;32:1491-6.

70. White AA, Simon RA. The blocking effect of essential controller medications during aspirin challenges in patients with aspirin exacerbated respiratory disease. Ann Allergy Asthma Immunol 2005;95:330-5.

71. Melillo G, Balzano G, Bianco S, Dahlen B, Godard P, Kowalski ML. Report of the INTERASMA Working Group on Standardization of Inhalation Provocation Tests in Aspirin-induced Asthma. Oral and inhalation provocation tests for the diagnosis of aspirin-induced asthma. Allergy 2001;56:899-911.

72. Pawlowicz A, Williams WR, Davies BH. Inhalation and nasal challenge in the diagnosis of aspirin induced asthma. Allergy 1991;46: 405-9.

73. White AA, Stevenson DD. Intranasal ketorolac challenge for the diagnosis of aspirin exacerbated respiratory disease. Ann Allergy Asthma Immunol. 2006 In press.

74. Yamashita T, Tsuyi H, Maeda N, Tomoda K, Kumazawa T. Etiology of nasal polyps associated with aspirin-sensitive asthma. Rhinology 1989;8:15-24.

75. Sladek K, Dworski R, Soja J, Sheller JR, Nizankowska E, Oates JA, et al. Eicosanoids in bronchoalveolar lavage fluid of aspirin-intolerant patients with asthma after aspirin challenge. Am J Respir Crit Care Med 1994;149:940-6.

76. Bachert C, Wagenmann M, Hauser U, Rudack C. IL-5 synthesis is upregulated in human nasal polyp tissue. J Allergy Clin Immunol 1997;99:837-42.

77. Bachert C, Wagenmann M, Rudack C, Hopken K, Hillebrandt M, Wang D, et al. The role of cytokines in infectious sinusitis and nasal polyposis. Allergy 1998;53:2-13.

78. Hamilos D, Leung DYM, Wood R, Cunningham L, Bean DK, Yasruel Z. Evidence for distinct cytokine expression in allergic versus nonallergic chronic sinusitis. J Allergy Clin Immunol 1995;96:537-44.

79. Sousa AR, Lams BE, Pfister R, Christie PE, Schmitz M, Lee TH. Expression of interleukin-5 and granulocyte-macrophage colonystimulating factor in aspirin-sensitive and non-aspirin-sensitive asthmatic airways. Am J Respir Crit Care Med 1997;156:1384-9. 
80. Elsner J, Hochstetter R, Kimming D, Kapp A. Human eotaxin represents a potent activator of the respiratory burst in human eosinophils. Eur J Immunol 1996;26:1919-25.

81. Kanaoka Y, Boyce J. Cysteinyl leukotrienes and their receptors: cellular distribution and function in immune and inflammatory responses. J Immunol 2004;173:1503-10.

82. Weller CL, Collington S, Brown KW, Miller HR, Al-Kashi A, Clark P, et al. Leukotriene B4, activation product of mast cells, is a chemoattractant for their progenitors. J Exp Med 2005;201:1961-71.

83. Cowburn AS, Sladek K, Soja J, Adamek L, Nizankowska E, Szczeklik A, et al. Over expression of leukotriene $\mathrm{C} 4$ synthase in bronchial biopsies from patients with aspirin-intolerant asthma. J Clin Invest 1998 101:834-46

84. Ziroli NE, Na H, Chow JM, Stankiewicz JA, Samter M, Young MR Aspirin-sensitive versus non-aspirin-sensitive nasal polyp patients: analysis of leukotrienes/Fas and Fas-ligand expression. Otolaryngol Head Neck Surg 2002;126:141-6.

85. Bachert C, Gevaert P, Van Cauwengerge P. Nasal polyposis-a new concept on the formation of polyps. ACI Int 1999;11:130-5.

86. Daffern P, Muilenburg D, Hugli TE, Stevenson DD. Association of urinary leukotriene E4 excretion during aspirin challenges with severity of respiratory responses. J Allergy Clin Immunol 1999;104:559-64.

87. Szczeklik A, Sladek K, Dworski R, Nizankowska E, Soja J, Oates J. Bronchial aspirin challenge causes specific eicosanoid response in aspirinsensitive asthmatics. Am J Respir Crit Care Med 1996;154:1608-14.

88. Christie PE, Tagari P, Ford-Hutchinson AW, Charlesson S, Chee P, Arm JP. Urinary leukotriene E4 concentrations increase after aspirin challenge in aspirin-sensitive asthmatic subjects. Am Rev Respir Dis 1991;143:1025-9.

89. Smith CM, Hawksworth RJ, Thien FC, Christie PE, Lee TH. Urinary leukotriene E4 in bronchial asthma. Eur Respir J 1992;5:693-9.

90. Sanak M, Pierzchalska M, Bazan-Socha S, Szczeklik A. Enhanced expression of the leukotriene $\mathrm{C}(4)$ synthase due to overactive transcription of an allelic variant associated with aspirin-intolerant asthma Am J Respir Cell Mol Biol 2000;23:290-6.

91. Sanak M, Simon HU, Szczeklik A. Leukotriene C4 synthase promotor polymorphism and risk of aspirin-induced asthma. Lancet 1997;350: 1599-600.

92. Van Sambeek R, Stevenson DD, Baldasaro M, Lam BK, Zhao J, Yoshida $\mathrm{S}$, et al. $5^{\prime}$ flanking region polymorphism of the gene encoding leukotriene C4 synthase does not correlate with the aspirin-intolerant asthma phenotype in the United States. J Allergy Clin Immunol 2000;106:72-6.

93. Sanak M, Szczeklik A. Leukotriene C4 synthase polymorphism and aspirin-induced asthma. J Allergy Clin Immunol 2001;107:561-2.

94. Sousa A, Parikh A, Scadding G, Corrigan CJ, Lee TH. Leukotrienereceptor expression on nasal mucosal inflammatory cells in aspirinsensitive rhinosinusitis. N Engl J Med 2002;347:1524-6.

95. Powell WS, Rokach J. Biochemistry, biology, chemistry of the 5-lipoxygenase product 5-oxo-ETE. Prog Lipid Res 2005;44:154-83.

96. Sanak M, Levy BD, Clish CB, Chiang N, Gronert K, Mastalerz L, et al Aspirin-tolerant asthmatics generate more lipoxins than aspirin- intolerant asthmatics. Eur Respir J 2000;16:44-9.

97. Nasser MS. Products of 15-LO: Are they important in asthma? Clin Exp Allergy 2002;32:1540-2.

98. Levy BD, DeSanctis GT, Devhand PR, Kim E, Ackerman K, Schmid $\mathrm{BA}$, et al. Multi-pronged inhibition of airway hyper-responsiveness and inflammation by lipoxin A4. Nat Med 2002;8:1018-23.

99. Perez-Novo CA, Watelet JB, Claeys C, Van Cauwenberge P, Bachert C. Prostaglandin, leukotriene and lipoxin balance in chronic rhinosinusitis with and without nasal polyps. J Allergy Clin Immunol 2005;115: 1189-96.

100. Kowalski ML, Bienkiewicz B, Pawliczak R, DuBuske L. Differentia effects of aspirin and misoprostol on 15-hydroxyeicosatetraenoic acid generated by leukocytes from aspirin sensitive asthmatic patients. J Allergy Clin Immunol 2003;112:505-12.

101. Bochenek G, Nagraba K, Nizankowska E, Szczeklik A. A controlled study of 9alpha11beta-PGF2 (a PGD2 metabolite) in plasma and urine of patients with bronchial asthma and healthy controls after aspirin challenges. J Allergy Clin Immunol 2003;111:743-9.

102. Monneret G, Cossett C, Gravel S, Rokack J, Powell WS. 15R-methylprostaglandin D2 is a potent and selective CRTH/DP2 receptor agonist in human eosinophils. J Pharmacol Exp Ther 2003;304:349-55.
103. Powell WS. A novel PGD2 receptor expressed in eosinophils. Prostaglandins Leukot Essent Fatty Acids 2003;69:179-85.

104. Szczeklik A. Prostaglandin E2 and aspirin-induced asthma [letter]. Lancet 1995;345:1056.

105. Schaefer D, Gode UC, Baenkler HW. Dynamics of eicosanoids in peripheral blood cells during bronchial provocation in aspirin-intolerant asthmatics. Eur Respir J 1999;13:638-46.

106. Jinnai N, Sakagami T, Sekigawa T, Kakihara M, Nakjima T, Yoshia K, et al. Polymorphisms in the prostaglandin E2 receptor subtype 2 gene confer susceptibility to aspirin-intolerant asthma: a candidate gene approach. Hum Mol Genet 2004;15:3203-17.

107. Ying S, Meng Q, Scadding G, Parikh A, Corrigan CJ, Lee TH. Aspirinsensitive rhinosinusitis is associated with reduced E-prostanoid 2 receptor expression. J Allergy Clin Immunol 2006;117:312-8.

108. Kunikata T, Yamane H, Segi E, Matsuoka T, Sugimoto Y, Tanaka S, et al. Suppression of allergic inflammation by the prostaglandin E receptor subtype EP3. Nat Immunol 2005;6:524-31.

109. Szczeklik A, Sanak M. The broken balance in aspirin hypersensitivity. Eur J Pharmacol 2006;533:145-55.

110. Choi JH, Park H, Oh HB, Lee JH, Suh YJ, Park CS, et al. Polymorphism of tandem repeat in promoter of 5-lipoxygenase in ASA-intolerant asthma: a positive association with airway hyper responsiveness. Hum Genet 2004;114:337-44.

111. Choi JH, Lee KW, Oh HB, Lee KJ, Suh YJ, Park CS, et al. HLA association in aspirin intolerant asthma: DPB $1 * 0301$ as a strong marker in a Korean population. J Allergy Clin Immunol 2004;113:562-4.

112. Dekker JW, Nizankowska E, Schmitz-Schumann M, Pile K, Bochenek G, Dyczek A, et al. Aspirin-induced asthma and HLA-DRB1 and HLADPB1 genotypes. Clin Exp Allergy 1997;27:574-7.

113. Kedda MA, Worsley P, Shi J, Phelps S, Duffy D, Thompson PJ. Polymorphisms in the 5-lipoxygenase activating protein (ALOX5AP) gene are not associated with asthma in an Australian population. Clin Exp Allergy 2005;35:332-8

114. Kim SH, Bae J, Suh CH, Nahm DH, Holloway JW, Park HS. Polymorphism of tandem repeat in promoter of 5-lipoxygenase in ASA-intolerant asthma: a positive association with airway hyperresponsiveness. Allergy 2005;60:760-5.

115. Szczeklik A. Adverse reactions to aspirin and nonsteroidal anti-inflammatory drugs. Ann Allergy 1987;59:113-8.

116. Kumlin M, Dahlen B, Bjorck T, Zetterstrom O, Granstrom E, Dahlen SE. Urinary excretion of leukotriene E4 and 11-dehydro-thromboxane B2 in response to bronchial provocations with allergen, aspirin, leukotriene D4, and histamine in asthmatics. Am Rev Respir Dis 1992;146: 96-103.

117. Ferreri NR, Howland WC, Stevenson DD, Spiegelberg HL. Release of leukotrienes, prostaglandins, and histamine into nasal secretions of aspirin-sensitive asthmatics during reaction to aspirin. Am Rev Respir Dis 1988;137:847-54.

118. Fischer AR, Rosenberg MA, Lilly CM, Callery JL, Rubin P, Cohn P. Direct evidence for a role of the mast cell in the nasal response to aspirin in aspirinsensitive asthma. J Allergy Clin Immunol 1994;94:1046-56.

119. Kowalski ML, Sliwinska-Kowalska M, Igarashi Y, White MV, Wojciechowska B, Brayron P, et al. Nasal secretions in response to acetylsalicylic acid. J Allergy Clin Immunol 1993;91:580-98.

120. Szczeklik A, Stevenson DD. Aspirin-induced asthma: advances in pathogenesis, diagnosis and management. J Allergy Clin Immunol 2003; 111:913-21.

121. Sestini P, Armetti L, Gambaro G, Peroni MG, Refini RM, Sala A, et al Inhaled PGE2 prevents aspirin-induced bronchoconstriction and urinary LTE4 excretion in aspirin-sensitive asthma. Am J Respir Crit Care Med 1996; 153:572-5

122. Szczeklik A, Mastalerz L, Nizankowska E, Cmiel A. Protective an bronchodilator effects of prostaglandin $\mathrm{E}$ and salbutamol in aspirininduced asthma. Am J Respir Crit Care Med 1996;153:567-71.

123. Picado C, Fernandez-Morata JC, Juan M, Roca-Ferrer J, Fuentes M, Xaubet A, et al. Cyclooxygenase- 2 mRNA is down expressed in nasal polyps from aspirin-sensitive asthmatics. Am J Respir Crit Care Med 1999;160:291-6.

124. Pujols L, Mullol J, Alobid I, Roca-Ferrer J, Xaubet A, Picado C. Dynamics of COX-2 in nasal mucosa and nasal polyps from aspirintolerant and aspirin-intolerant patients with asthma. J Allergy Clin Immunol 2004; 114:814-9. 
125. Arm JP, O'Hickey SP, Spur BW, Lee TH. Airway responsiveness to histamine and leukotriene E4 in subjects with aspirin-induced asthma. Am Rev Respir Dis 1989;140:148-53.

126. Kowalski M, Grzegorczy J, Wojciechowska B, Sponiatowska M. Intranasal challenge with aspirin induces cell influx and activation of eosinophils and mast cells in nasal secretions of ASA-sensitive patients. Clin Exp Allergy 1996;26:807-14.

127. Bosso JV, Schwartz LB, Stevenson DD. Tryptase and histamine release during aspirin-induced respiratory reactions. J Allergy Clin Immunol 1991;88:830-7.

128. Juergens UR, Christiansen SC, Stevenson DD, Zuraw BL. Inhibition of monocyte leukotriene B4 production following aspirin desensitization. J Allergy Clin Immunol 1995;96:148-56.

129. Mastalerz L, Milewski M, Duplaga M, Nizankowska E, Szczeklik A. Intranasal fluticasone propionate for chronic eosinophilic rhinitis in patients with aspirin-induced asthma. Allergy 1997;52:895-900.

130. Mathison DA, Stevenson DD. Aspirin sensitivity in rhinosinusitis and asthma. Immunol Allergy Pract 1983;5:340-50.

131. Dahlen SE, Nizankowska E, Dahlen B, Szczeklik A. The SwedishPolish treatment study with the 5-lipoxygenase inhibitor Zileuton in aspirin-intolerant asthmatics. Am J Respir Crit Care Med 1995;151: 376.

132. Dahlen B, Nizankowska E, Szczeklik A, Zetterstrom O, Bochenek G, Kumlin M, et al. Benefits from adding the 5-lipoxygenase inhibitor zileuton to conventional therapy in aspirin-intolerant asthmatics. Am J Respir Crit Care Med 1998;157:1187-94.

133. Dahlen S, Malstrom K, Nizankowska E, Dahlen B, Kuna P, Kowalski $\mathrm{M}$, et al. Improvement of aspirin-intolerant asthma by montelukast, a leukotriene antagonist: A randomized, double blind, placebo controlled trial. Am J Respir Crit Care Med 2002;165:9-14.

134. Mastalerz L, Nizankowska E, Sanak M, Mejza F, Pierzchalska M, Bazan-Socha S, et al. Clinical and genetic features underlying the response of patients with bronchial asthma to treatment with a leukotriene receptor antagonist. Eur J Clin Invest 2002;32:949-55.

135. Mastalerz L, Niżankowska E, Ćmiel A, Szczeklik A. Protection against exercise-induced bronchoconstriction by montelukast in aspirin-sensitive and aspirin-tolerant patients with asthma. Clin Exp Allergy 2002;32: $1360-5$.
136. Sampson AP, Siddiqui S, Buchanan D, Howarth PH, Holgate ST, Holloway JW, et al. Variant LTC(4) synthase allele modifies cysteinyl leukotriene synthesis in eosinophils and predicts clinical response to zafirlukast. Thorax 2000;55(suppl):S28-31.

137. Asano K, Shiomi T, Hasegawa N, Nakamura H, Kudo H, Matsuzaki T, et al. Leukotriene $\mathrm{C} 4$ synthase gene $\mathrm{A}(-444) \mathrm{C}$ polymorphism and clinical response to an LT(1) antagonist, pranlukast, in Japanese patients with moderate asthma. Pharmacogenetics 2002;12:565-70.

138. Park HE, Kim SH, Sampson A, Lee KW, Park CS. The HLADPB $1 * 0301$ marker might predict the requirement for leukotriene receptor antagonist in patients with aspirin-intolerant asthma. J Allergy Clin Immunol 2004:114:688-9.

139. McFadden EA, Woodson BT, Fink JN, Toohill RJ. Surgical treatment of aspirin triad sinusitis. Am J Rhinol 1997;11:263-70.

140. Kennedy DW. Prognostic factors, outcomes and staging in ethmoid sinus surgery. Laryngoscope 1992;102:1-18.

141. Amar YG, Frenkiel S, Sobol SE. Outcome analysis of endoscopic sinus surgery for chronic sinusitis in patients having Samter's triad. J Otolaryngol 2000;29:7-12

142. Sweet JA, Stevenson DD, Simon RA, Mathison DA. Long term effects of aspirin desensitization treatment for aspirin sensitive rhinosinusitis asthma. J Allergy Clin Immunol 1990;86:59-65.

143. Pleskow WW, Stevenson DD, Mathison DA, Simon RA, Schatz M, Zieger RS. Aspirin desensitization in aspirin sensitive asthmatic patients: Clinical manifestations and characterization of the refractory period. J Allergy Clin Immunol 1982;69:11-9.

144. Berges-Gimeno M, Simon RA, Stevenson DD. Early effects of aspirin desensitization treatment in asthmatics with aspirin exacerbated respiratory disease. Ann Allergy Asthma Immunol 2003;90:1-4.

145. Berges-Gimeno M, Simon RA, Stevenson DD. Treatment with aspirin desensitization in patients with aspirin exacerbated respiratory disease. J Allergy Clin Immunol 2003;111:180-6.

146. Stevenson DD, Hankammer MA, Mathison DA, Christensen SC, Simon RA. Long term ASA desensitization-treatment of aspirin sensitive asthmatic patients: clinical outcome studies. J Allergy Clin Immunol 1996; 98:751-8.

147. Stevenson DD. Aspirin desensitization in patients with AERD. Clin Rev Allergy Immunol 2003;24:159-67. 